\title{
COMBINED DRUG TREATMENT OF TUBERCULOSIS. II. STUDIES OF ANTIMICROBIALLY-ACTIVE ISONIAZID AND STREPTO- MYCIN SERUM LEVELS IN ADULT TUBERCULOUS PATIENTS
}

\author{
By WILLIAM MANDEL, ANGELINE D. HEATON, WILLIAM F. RUSSELL, JR. AND \\ GARDNER MIDDLEBROOK \\ (From the Department of Research and Laboratories, National Jezish Hospital at Denver, and \\ the Departments of Medicine and Microbiology, University of Colorado School \\ of Medicine, Denver, Colo.)
}

(Submitted for publication September 10, 1958; accepted February 23, 1959)

The importance of achieving concentrations of both streptomycin and isoniazid adequate to sterilize all parent drug-susceptible organisms was empasized by in vitro studies on the prevention of emergence of mutants resistant to these drugs (1). Many factors determine the concentrations of these agents to which multiplying tubercle bacilli are exposed in the human subject: dosage; absorption and excretion; metabolic alteration; binding to protein; and diffusion into lesions, tissues and cells. Furthermore, with streptomycin the problem is complicated by the presence of substances in the lesions which antagonize the antibacterial action of the drug.

Metabolic alteration of isoniazid has been estimated from serum levels of antimicrobially-active drug collected at intervals following a test dose $(2,3)$. Isoniazid is altered to derivatives such as acetyl-isoniazid and isonicotinic acid which have little or no antimicrobial activity $(4,5)$. Bönicke and Reif (6), Cuthbertson, Ireland, Wolff and Kuper (7), and Hughes, Schmidt and Biehl (8) have found that the rate of metabolic alteration of the isoniazid molecule varies widely in different individuals. Mandel, Cohn, Russell and Middlebrook (9) demonstrated a significant relationship between this rate of metabolic alteration of isoniazid and the bacteriologic response in isoniazid-treated tuberculous patients. The chemical methods thus far described for the determination of isoniazid (10-14) are not practical for the antimicrobially-active moiety, as they are neither sufficiently sensitive nor specific to permit measurement of the low concentrations present in the sera of many subjects receiving conventional dosages of this drug.

Streptomycin serum concentrations have been investigated, and apparently this drug is not subject to significant metabolic alteration (15). There were differences between the serum concentrations of streptomycin achieved by four different subjects (16). Most studies have tended to emphasize the uniformity of the handling of streptomycin from subject to subject (17-20). However, very few human subjects were used.

The purpose of this report (the second of a series) is to present our experiences with specific microbiologic assays for isoniazid and streptomycin performed on sera from isoniazid- and streptomycin-treated adult tuberculous patients, and to discuss the clinical significance of the results.

\section{MATERIALS AND METHODS}

Microbiologic assay for serum isoniazid was performed as previously described (2). Isoniazid was given in total dosage of 8 to $16 \mathrm{mg}$. per $\mathrm{Kg}$. daily for at least one day prior to the test. The initial study in most patients consisted of an assay on a blood specimen obtained by venipuncture at six hours after a $4 \mathrm{mg}$. per $\mathrm{Kg}$. oral test or loading dose of isoniazid (given at 9:00 a.m.). Streptomycin ( $20 \mathrm{mg}$. per $\mathrm{Kg}$.) was uniformly administered along with isoniazid on this first test day. The patients were not fasting, but this has not significantly modified the results of this assay as performed in our laboratory (2). With the exception of insulin in the case of diabetics, no other drugs were given on the test day. Para-aminosalicylic acid (NaPAS) was not administered for at least two days prior to the test.

A. Reproducibility of the microbiologic assay test for isoniazid. The reproducibility of the microbiologic assay test for isoniazid was investigated by performing the serial twofold tube dilutions containing known concentrations of isoniazid, inoculating the tubes with suspensions of dispersed, vigorously growing H37RvRSM organisms $(\mathrm{RSM}=$ resistant to $2.0 \mu \mathrm{g}$. streptomycin per $\mathrm{ml}$. and susceptible to isoniazid), incubating at $36^{\circ} \mathrm{C}$. for five days, and reading the results in terms of loss of acid- 
TABLE I

Effect of various drugs on antimicrobially-active serum isoniazid level at six hours after a 4 to $8 \mathrm{mg}$. per Kg. test dose of isoniazid

\begin{tabular}{|c|c|c|c|c|c|}
\hline \multirow{2}{*}{\multicolumn{2}{|c|}{ Drug }} & \multirow[b]{2}{*}{ Patients } & \multirow{2}{*}{$\begin{array}{l}\text { Dosage, and time } \\
\text { of administration } \\
\text { related to test dose }\end{array}$} & \multicolumn{2}{|c|}{ Number of patients with } \\
\hline & & & & Increase & $\begin{array}{l}\text { No detectable } \\
\text { change }\end{array}$ \\
\hline \multicolumn{2}{|c|}{ 1. PAS } & $\begin{array}{r}140 \\
5 \\
5 \\
5\end{array}$ & $\begin{array}{l}2.5 \mathrm{Gm} \text {. at } 0 \text { and } 3 \mathrm{hrs} \text {. } \\
1 \mathrm{Gm} \text {. at } 0 \text { and } 3 \mathrm{hrs} \text {. } \\
5 \mathrm{Gm} \text {. at } 0 \text { hrs. } \\
2 \mathrm{Gm} \text {. at } 0 \mathrm{hrs} \text {. }\end{array}$ & $\begin{array}{r}116 \\
0 \\
2 \\
1\end{array}$ & $\begin{array}{r}24 \\
5 \\
3 \\
4\end{array}$ \\
\hline \multirow{2}{*}{\multicolumn{2}{|c|}{$\begin{array}{ll}\text { 2. } & \text { PABA } \\
\text { 3. } & \text { Probenecid }\end{array}$}} & $\begin{array}{r}71 \\
5\end{array}$ & $\begin{array}{l}2.5 \mathrm{Gm} \text {. at } 0 \text { and } 3 \text { hrs. } \\
2 \mathrm{Gm} \text {. daily for } 2 \text { days }\end{array}$ & 65 & 6 \\
\hline & & & $500 \mathrm{mg}$. at 0 and $3 \mathrm{hrs}$. & $\mathbf{0}$ & 5 \\
\hline \multirow{2}{*}{\multicolumn{2}{|c|}{ 4. Phenylbutazone }} & 3 & $300 \mathrm{mg}$. at 0 and $3 \mathrm{hrs}$. & 0 & 3 \\
\hline & & 2 & $600 \mathrm{mg}$. at $0 \mathrm{hrs}$ & $\mathbf{0}$ & 2 \\
\hline \multirow{2}{*}{\multicolumn{2}{|c|}{$\begin{array}{l}\text { 5. Barbituric acid } \\
\text { 6. Phenobarbital }\end{array}$}} & $\begin{array}{l}3 \\
2\end{array}$ & $\begin{array}{l}2.5 \mathrm{Gm} . \text { at } 0 \text { and } 3 \mathrm{hrs} . \\
60 \mathrm{mg} .2 \mathrm{hrs} \text {. before }\end{array}$ & 0 & 3 \\
\hline & & & $60 \mathrm{mg}$. at 0 and $3 \mathrm{hrs}$. & 0 & 2 \\
\hline \multicolumn{2}{|c|}{ 7. Secobarbital } & 2 & $45 \mathrm{mg} .2$ hrs. before & & \\
\hline \multirow{2}{*}{\multicolumn{2}{|c|}{ 8. Amobarbital }} & 2 & $90 \mathrm{mg} .2$ hrs. before & 0 & 2 \\
\hline & & & $90 \mathrm{mg}$. at 0 and $3 \mathrm{hrs}$. & 0 & 2 \\
\hline \multirow{5}{*}{$\begin{array}{r}9 . \\
10 . \\
11 . \\
12 . \\
13 .\end{array}$} & Glucosamine & 3 & $3.5 \mathrm{Gm}$. at 0 and $3 \mathrm{hrs}$. & 0 & 3 \\
\hline & Chlorpromazine & 6 & $25 \mathrm{mg}$. at 0 and $3 \mathrm{hrs}$. & $\mathbf{0}$ & 6 \\
\hline & Prednisone & 5 & $25 \mathrm{mg}$. at 0 and $3 \mathrm{hrs}$. & 0 & 5 \\
\hline & Sodium salicylate & 5 & $2.5 \mathrm{Gm}$. at 0 and $3 \mathrm{hrs}$. & 0 & 5 \\
\hline & & & $100 \mathrm{mg}$. at 0 and $3 \mathrm{hrs}$. & 0 & 7 \\
\hline
\end{tabular}

fastness (2). Fifty such tests were performed by one individual during a four month period.

It should be noted that the microbiologic assay for isoniazid, originally described by Mandel and associates (2), and employed here, differs significantly from other methods described in the literature $(3,21,22)$. Not only is it more specific for isoniazid by virtue of the fact that the end-point is determined by loss of acid-fastness ${ }^{1}$ rather than by gross evidence of inhibition of growth, but it also requires a shorter period of time for its performance, i.e., five days versus the 10 days required for these other methods.

B. Serum isoniazid levels at six hours after a single loading dose. The initial microbiologic assay test was performed on 254 hospitalized adult tuberculous patients.

C. Reproducibility of serum level studies repeated on the same individuals. Isoniazid serum level studies were repeated at least once on 163 patients. The interval between the first and subsequent studies was from one day to six months. The greatest number of such studies repeated on any one individual was five.

D. Effect of increasing the loading dose of isoniazid from 4 to $8 \mathrm{mg}$. per $K \mathrm{~g}$. The effect of increasing the loading dose of isoniazid from 4 to $8 \mathrm{mg}$. per $\mathrm{Kg}$. was

1 Following the report that streptomycin administered first could prevent the isoniazid-produced loss of acidfastness, this was studied in the sera from some of our patients. The presence or absence of streptomycin in the serum did not alter the result of the microbiologic assay for isoniazid, because a streptomycin-resistant strain was employed. studied in 54 patients whose initial serum levels had been $0.2 \mu \mathrm{g}$. or more of isoniazid per $\mathrm{ml}$. of serum at six hours following a $4 \mathrm{mg}$. per $\mathrm{Kg}$. test dose.

E. Comparison of a "rapid" with a "slow" inactivator of isoniazid by both chemical and microbiologic methods. Serum levels of antimicrobially-active isoniazid as well as isoniazid plus its derivatives were determined on serial specimens of sera from two patients: One achieved a lowv and the other $a$ high level following the $4 \mathrm{mg}$. per $\mathrm{Kg}$. test dose. The method of determination of isoniazid plus its derivatives was based on assay for isonicotinic acid after complete hydrolysis and oxidation, and was reported as isoniazid equivalent (10). Blood was drawn for analysis at zero, two, four, six and 24 hours following an $8 \mathrm{mg}$. per $\mathrm{Kg}$. test dose of isoniazid. The same study was repeated with $2.5 \mathrm{Gm}$. of para-aminosalicylic acid (2.85 Gm. NaPAS) added to the test dose of isoniazid. Para-aminosalicylic acid, $2.5 \mathrm{Gm}$., was also given at three, six and nine hours after the test dose.

F. Effect of various drugs on the scrum isoniazid level. The effects of 13 different compounds on the antimicrobially-active serum isoniazid level were studied. Determinations were made on 160 serum specimens from 79 patients selected at random whose initial determinations revealed active serum levels below $0.4 \mu \mathrm{g}$. per $\mathrm{ml}$. At the start of the drug testing program, the lowest dilution of serum employed was one to 10 , but one to five dilutions were included later so that lower concentrations of isoniazid could be detected. All drugs except isoniazid were discontinued for at least one day prior to the test. On the test day, the patient usually was given a $4 \mathrm{mg}$. per $\mathrm{Kg}$. dose of isoniazid plus one-half of the total dose 
of the other drug at zero time. The second portion of the test drug was given three hours later (three hour time), and the blood was drawn for analysis three hours later (six hour time). This procedure varied slightly with different drugs and in different subjects. Control determinations without the administration of the test drug were usually performed within one week of the test. For comparative purposes, an attempt was made to use various drugs in the same subject when it was found that one drug increased the antimicrobially-active serum level of isoniazid. The drugs used, the dosages given, and the number of patients studied are listed in Tables I and II.

G. Comparison of isoniazid levels in serum and in cavity content. Surgical resections of closed cavities filled with caseous necrotic debris were performed on five patients. The specimens were removed approximately six hours after a $4 \mathrm{mg}$. per $\mathrm{Kg}$. oral loading dose of isoniazid. At the same time blood was drawn so that a comparison could be made between the antimicrobially-active drug level in serum and in cavity content.

H. Microbiologic assay test for streptomycin. The concentration of streptomycin in sera was determined microbiologically by a filter-paper disc-seeded agar diffusion method similar to that described by Forgacs, Kornegay and Henley (23). Bacto antibiotic medium 5 (Difco Laboratories, Inc., Detroit, Mich.), $\mathrm{pH} 8$, was used as the test medium, and Bacillus subtilis "I" strain (obtained from the Army Medical Department, Research and Graduate School, Walter Reed Hospital, Washington, D.C.) was the test organism. An important modification of previously described filter-paper disc agar diffusion methods was employed in this study: The final seeded plate with test discs in place was stored at $4^{\circ} \mathrm{C}$. for 48 hours before incubation at $36^{\circ} \mathrm{C}$. This greatly improved the sensitivity and accuracy of the method and permitted the use of undiluted sera for impregnation of the filter-paper discs. It permitted estimation of streptomycin concentrations between 5 and $50 \mu \mathrm{g}$. per $\mathrm{ml}$. of serum. For each series of assays, a standard curve was obtained relating diameters of zones of growth inhibition to known concentrations of streptomycin, 5.6, 11.2, 22.5 and $40 \mu \mathrm{g}$. of streptomycin per $\mathrm{ml}$. in duplicate.

I. Serum streptomycin levels at six hours after a single intramuscular loading dose. Each of 116 patients was given streptomycin sulfate, $20 \mathrm{mg}$. per $\mathrm{Kg}$. of body weight, intramuscularly, and six hours later blood was drawn for testing. The venous blood sample was allowed to clot at room temperature, the clot was separated aseptically, and the serum stored at $4^{\circ} \mathrm{C}$. until testing (within one week).

$J$. Reproducibility of serum streptomycin lez'el studics on the same individuals. Repeat studies were performed on 157 patients under the same conditions at intervals of one day to seven months.

$K$. Correlation of in vitro drug resistance with serum streptomycin levels achiez'ed by patients excreting resistant organisms. The precise level of streptomycin resistance manifested by tubercle bacilli recovered from the sputum of 33 patients who were excreting organisms resistant to streptomycin on admission was studied quantitatively. The populations of tubercle bacilli from 16 of these patients were completely resistant to $2.0 \mu \mathrm{g}$. of streptomycin per $\mathrm{ml}$, , but less than 50 per cent were resistant to $10 \mu \mathrm{g}$. of streptomycin per $\mathrm{ml}$. It was considered possible that this low level of resistance might have resulted from failure of these 16 patients to achieve sufficiently high serum streptomycin levels during previous treatment with this drug. The streptomycin serum levels of these 33 patients at six hours after a $20 \mathrm{mg}$. per $\mathrm{Kg}$. intramuscular loading dose of streptomycin were determined and correlated with the bacterial resistance findings.

TABLE II

The effect of para-aminosalicylic acid (PAS) and para-aminobenzoic acid $(P A B A)$ on the antimicrobially-active serum isoniazid level in nine patients

\begin{tabular}{|c|c|c|c|c|}
\hline Patients & $\begin{array}{l}\text { Time of determination } \\
\text { after } 4 \mathrm{mg} \text {. per } \mathrm{Kg} . \\
\text { test dose of isoniazid }\end{array}$ & Isoniazid alone & Isoniazid with PAS & Isoniazid with PABA \\
\hline \multirow{3}{*}{ L.S.* } & hrs. & $\mu g . / m l$. & $\mu g . / m l$. & $\mu g . / m l$. \\
\hline & 3 & 0.8 & 2.4 & 3.2 \\
\hline & 6 & 0.4 & 0.6 & 3.2 \\
\hline \multirow{2}{*}{ D.P.† } & 3 & 0.8 & 1.6 & 1.6 \\
\hline & 6 & 0.4 & 0.4 & 0.8 \\
\hline \multirow[t]{2}{*}{ F.H.† } & 3 & 0.8 & 0.8 & 0.8 \\
\hline & 6 & 0.2 & 0.4 & 1.6 \\
\hline \multirow{2}{*}{ P.Y.† } & 3 & 0.6 & 0.8 & 2.4 \\
\hline & 6 & 0.2 & 0.2 & 0.6 \\
\hline \multirow{2}{*}{ A.S.† } & 3 & 0.8 & 1.2 & 1.6 \\
\hline & 6 & 0.2 & 0.4 & 1.6 \\
\hline \multirow{4}{*}{$\begin{array}{l}\text { M.S.* } \\
\text { E.C.* } \\
\text { O.R. }{ }^{*} \\
\text { A.P. } \dagger\end{array}$} & 6 & 0.4 & 0.4 & 1.2 \\
\hline & 6 & 0.4 & 0.8 & 1.6 \\
\hline & 6 & 0.4 & 1.2 & 1.6 \\
\hline & 6 & 0.2 & 0.2 & 0.4 \\
\hline
\end{tabular}

* Five Gm. PAS or PABA given with test dose.

$\dagger$ Two and five-tenths Gm. of PAS of PABA given with test dose and three hours later. 


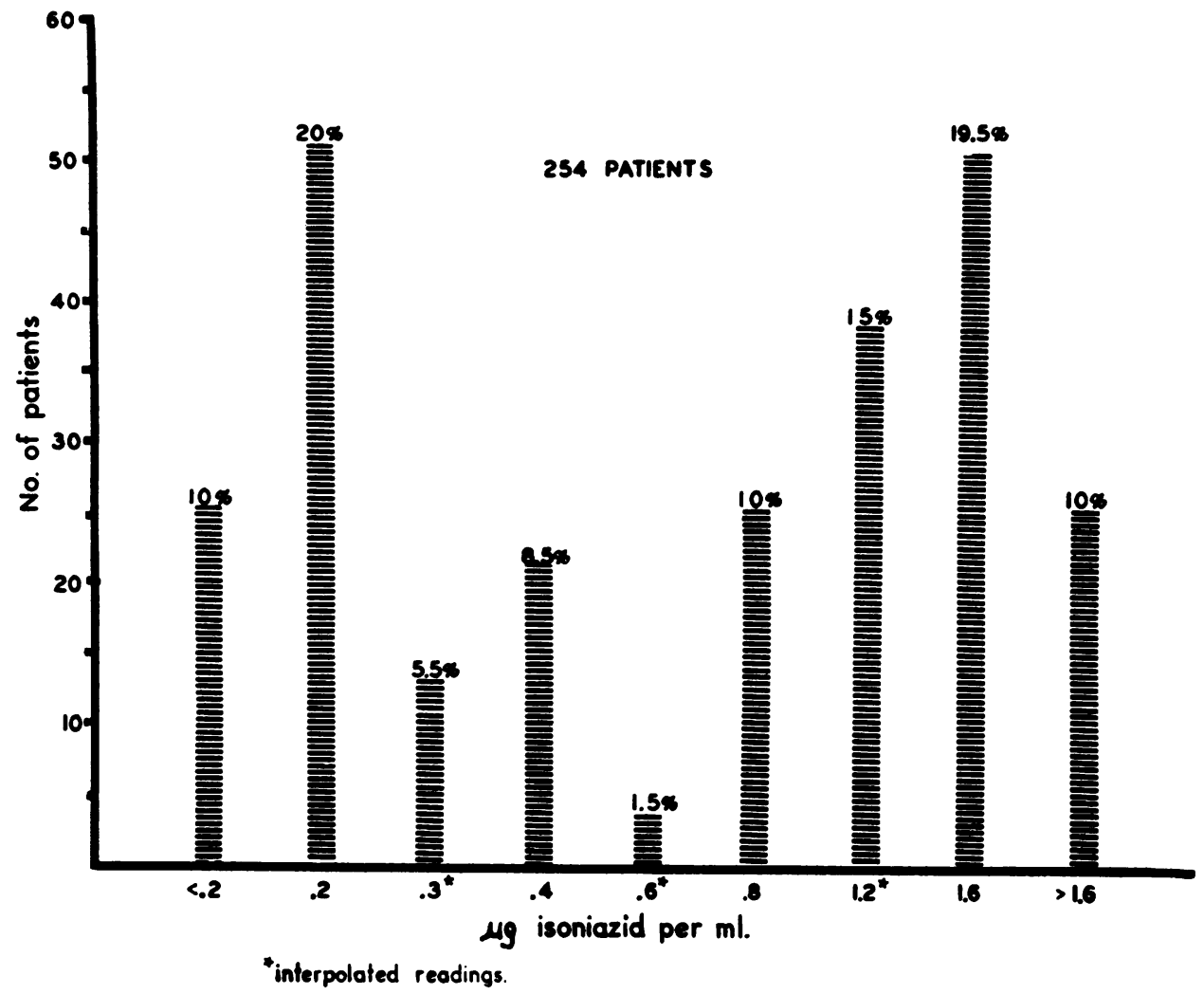

Fig. 1. Serum Isoniazid Levels

At six hours after $4 \mathrm{mg}$. isoniazid per $\mathrm{Kg}$.

RESULTS

\section{A. Reproducibility of the microbiologic assay test for isoniazid}

Analysis of 50 consecutive microbiologic assay tests with the test strain of H37RvRSM employed throughout these studies, and with known concentrations of isoniazid, gave a mean value of $0.037 \mu \mathrm{g}$. isoniazid per ml. of test medium as the minimal concentration of isoniazid causing 50 per cent loss of acid-fastness under the conditions described. These results were obtained by the same individual over a period of four months. The standard deviation of the results of this series provides an estimation of the accuracy of the microbiologic assay method : $\pm 0.007 \mu \mathrm{g}$. isoniazid per $\mathrm{ml}$. ( \pm 20 per cent $)$.

B. Serum isoniazid levels at six hours after a single loading dose

The distribution of values for antimicrobiallyactive levels of serum isoniazid at six hours after. an oral test dose of $4 \mathrm{mg}$. isoniazid per $\mathrm{Kg}$. of body weight in 254 hospitalized adult tuberculous patients is presented in Figure 1. The distribution curve of results has a clear-cut bimodal character: Approximately 55 per cent of these patients had levels above $0.6 \mu \mathrm{g}$. isoniazid per $\mathrm{ml}$. of serum with a peak between 1.2 and $1.6 \mu \mathrm{g}$. per ml., and 45 per cent, lower than this value, with a peak near $0.2 \mu \mathrm{g}$. per $\mathrm{ml}$. About 10 per cent of these patients were very rapid "inactivators" of the drug, having levels less than the minimum detectable level of $0.2 \mu \mathrm{g}$. per $\mathrm{ml}$.

\section{Reproducibility of serum level studies re- peated on the same individuals}

Isoniazid serum level studies at six hours after loading dosage of $4 \mathrm{mg}$. isoniazid per $\mathrm{Kg}$. were repeated once on 163 patients after one day to six month intervals. The standard deviation from the mean of the isoniazid serum level results of the two studies on each patient was \pm 28 per cent throughout the range 0.2 to $4.8 \mu \mathrm{g}$. isoniazid per 


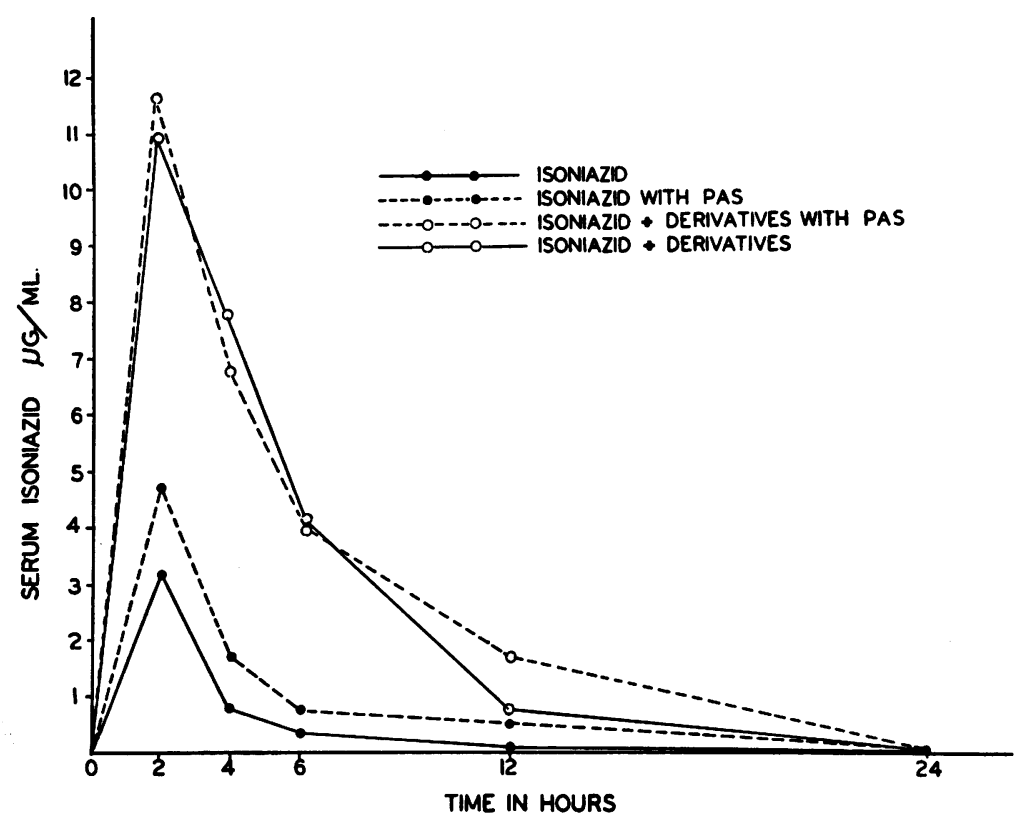

Fig. 2. Chemically Determined Serum Isoniazid Plus Derivatives Compared with Antimicrobially-Active Serum Isoniazid Both with and without Para-Aminosalicylic Acid in a Patient Who Inactivated IsoNIAZID RAPIDLY

ml. of serum. This can be compared with the standard deviation from the mean which is inherent in the microbiologic testing procedure itself, \pm 20 per cent.

\section{Effect of increasing the loading dose of ison- iazid from 4 to $8 \mathrm{mg}$. per $\mathrm{Kg}$.}

Isoniazid serum levels were obtained at six hours after a $4 \mathrm{mg}$. per $\mathrm{Kg}$. loading dose and after an $8 \mathrm{mg}$. per $\mathrm{Kg}$. loading dose in each of 54 patients. Only those individuals were included in this study whose serum levels after the $4 \mathrm{mg}$. per $\mathrm{Kg}$. loading dose were $0.2 \mu \mathrm{g}$. or more isoniazid per ml. of serum. Fifty-one of these patients had serum level increases, and the average increase was 125 per cent, or somewhat more than doubling of the serum level after doubling the loading dose of drug in this dosage range. Only three patients had no demonstrable increase.

\section{E. Comparison of a "rapid" with a "slow" inacti- vator}

The results of the determinations of isoniazid plus all its derivatives in a "rapid" and a "slow" inactivator are presented in Figures 2 and 3 . It will be noted that at six hours after the loading dose of isoniazid approximately 56 per cent of the total serum isoniazid was in an antimicrobiallyactive form in the "slow" inactivator, whereas only 5 per cent was in this form in the "rapid" inactivator. Over the 24 hour period, the "slow" inactivator had approximately five times more antimicrobially-active drug in the serum, expressed as $\mu \mathrm{g}$. hours per $\mathrm{ml}$. of serum, than did the "rapid" inactivator.

\section{F. Effect of various drugs on the isoniazid level}

The effect of the drugs tested is presented in Tables I, II and III. The original observation on the effect of administration of para-aminosalicylic acid (PAS) on the metabolism of isoniazid in human subjects was reported elsewhere by us (2). This observation has been confirmed by Morse and co-workers ( 3 ) and by Bell and Mitchell (22). Dosages of para-aminosalicylic acid of 2.5 $\mathrm{Gm}$. given at the zero and three hour times were more effective than the other dosage schedules studied.

The effects of para-aminosalicylic acid on the antimicrobially-active serum isoniazid level in a "rapid" and a "slow" inactivator have been shown 


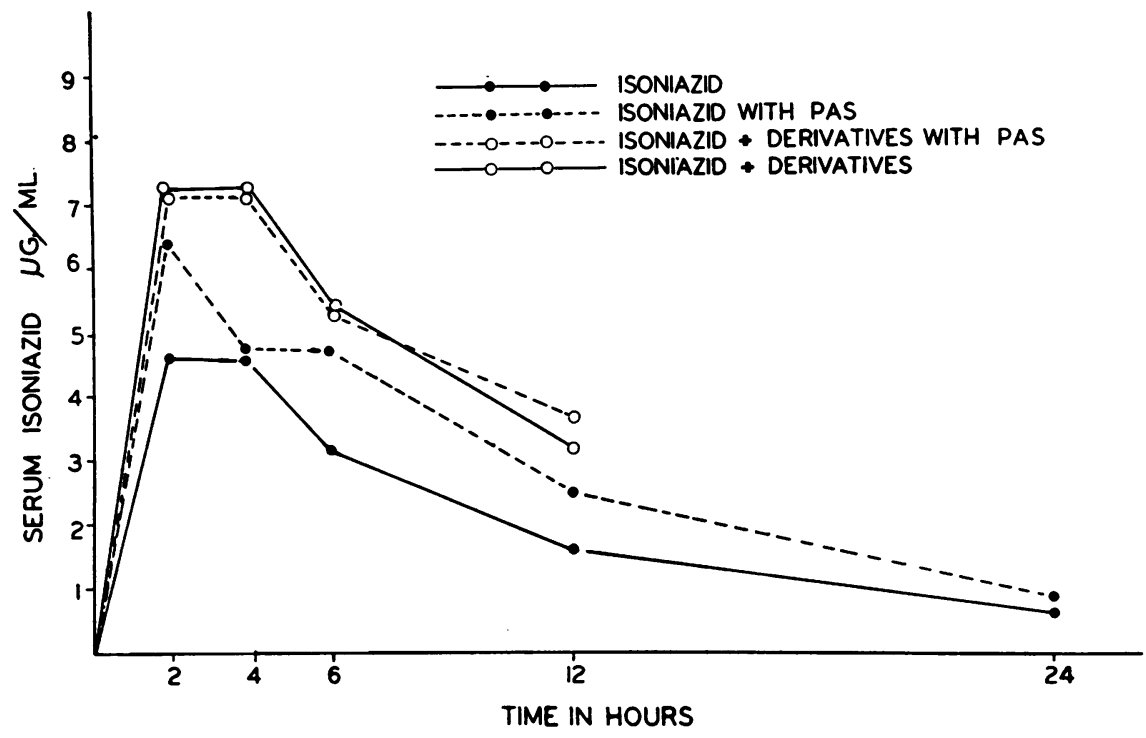

Fig. 3. Chemically Determined Serum Isoniazid Plus Derivatives Compared with Antimicrobially-Active Serum Isoniazid Both with and without ParaAminosalicylic Acid in a Patient who Inactivated Isoniazid Slowly

in Figures 2 and 3. The antimicrobially active level was increased in each instance, whereas there was no significant change in the level of isoniazid plus all its derivatives.

It has been demonstrated that: 1) The addition of para-aminosalicylic acid (1,000 $\mu \mathrm{g}$. per ml.) to the microbiologic assay medium does not modify the antimicrobial activity of isoniazid; 2) The addition of para-aminosalicylic acid to serum from patients receiving isoniazid does not alter the results of this test for antimicrobially-active isoniazid; and 3) The antimicrobial activity of isoniazid is not modified in vitro by serum (Table III) from patients receiving large oral doses of para-aminosalicylic acid. Therefore, the method of microbiologic assay prevents the in vitro antimicrobial action of para-aminosalicylic acid.

It is clear (Tables I and II) that the addition of para-aminobenzoic acid which has no direct antimycobacterial action led to a detectable increase in the antimicrobially-active serum isoniazid level in the 71 subjects tested, and that this increase was generally higher and more sustained than that achieved by para-aminosalicylic acid.

TABLE III

Effect of orally administered para-aminosalicylic acid (PAS) on results of microbiologic assay for isoniazid $(I N H)$ in serum

\begin{tabular}{|c|c|c|c|c|c|c|}
\hline \multirow[b]{3}{*}{ Subject } & \multicolumn{4}{|c|}{$\begin{array}{l}\text { INH administered orally } \\
18 \text { hours previously }\end{array}$} & \multicolumn{2}{|c|}{$\begin{array}{l}\text { INH } 8 \mathrm{mg} . / \mathrm{Kg} \text {. administered } \\
\text { orally } 6 \text { hours previously }\end{array}$} \\
\hline & \multicolumn{2}{|c|}{$\begin{array}{l}\text { No addition of INH } \\
\text { to serum }\end{array}$} & \multicolumn{2}{|c|}{ 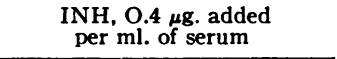 } & \multirow[b]{2}{*}{$\begin{array}{l}\text { Without } \\
\text { oral PAS }\end{array}$} & \multirow{2}{*}{$\begin{array}{c}\text { With } \\
\text { oral PAS, } \\
2.5 \mathrm{Gm} \text {. at } \\
0 \text { and } 3 \mathrm{hrs}\end{array}$} \\
\hline & $\begin{array}{l}\text { Without } \\
\text { oral PAS }\end{array}$ & $\begin{array}{c}\text { With } \\
\text { oral PAS* }\end{array}$ & $\begin{array}{l}\text { Without } \\
\text { oral PAS }\end{array}$ & $\begin{array}{l}\text { With } \\
\text { oral PAS* }\end{array}$ & & \\
\hline $\begin{array}{l}\text { A.L. } \\
\text { O.D. } \\
\text { O.R. } \\
\text { E.G. } \\
\text { S.K. } \\
\text { W.B. } \\
\text { W.R. }\end{array}$ & $\begin{array}{c}<0.2 \dagger \\
0.2 \\
0.2 \\
0.4 \\
0.4 \\
0.4 \\
<0.2\end{array}$ & $\begin{array}{c}<0.2 \\
0.2 \\
0.2 \\
0.4 \\
0.4 \\
0.4 \\
<0.2 \ddagger\end{array}$ & $\begin{array}{l}0.4 \\
0.6 \\
0.8 \\
0.8 \\
0.8 \\
0.8 \\
0.2\end{array}$ & $\begin{array}{l}0.6 \\
0.8 \\
0.8 \\
0.8 \\
0.8 \\
0.8 \\
0.4 \ddagger\end{array}$ & $\begin{array}{l}0.4 \\
0.8 \\
0.8 \\
4.8 \\
3.2 \\
1.6 \\
2.4\end{array}$ & $\begin{array}{l}1.2 \\
3.2 \\
2.4 \\
4.8 \\
6.4 \\
3.2 \\
4.8\end{array}$ \\
\hline
\end{tabular}

* PAS, $10 \mathrm{Gm}$. orally in one dose; blood collected at two and one-half hours.

$\dagger$ Micrograms INH per ml. of serum specimen, by microbiologic assay.

‡ Special dosage; PAS, $24 \mathrm{Gm}$. (30 Gm. NaPAS), taken $12 \mathrm{Gm}$. at zero hour and $12 \mathrm{Gm}$. at three hours; blood collected at six hours. 
Under the test conditions, the following drugs had no effect on the antimicrobially-active serum isoniazid level: probenecid, phenylbutazone, barbituric acid, other barbiturates, glucosamine, chlorpromazine hydrochloride, prednisone, sodium salicylate and pyridoxine. Those investigations which have shown that pyridoxine can antagonize the chemotherapeutic activity of isoniazid in mice were carried out with much larger ratios of pyridoxine to isoniazid than have been employed in human beings (21).

\section{G. Comparison of isoniazid levels in serum and in cavity content}

Obstructed tuberculous cavities, filled with caseous necrotic debris, were removed from five patients. Blood samples were collected at the same time. In each of these patients the serum level of antimicrobially-active isoniazid at six hours was the same, within the limits of error, as the level in the cavity content.

\section{H. Reproducibility of the microbiologic assay test for streptomycin}

Analysis of the duplicate results of 23 consecutive microbiologic assays for known concentrations of streptomycin sulfate gave the following results : mean, $5.6 \mu \mathrm{g}$. per $\mathrm{ml}$. (standard deviation, \pm 6 per cent) ; mean, $11.2 \mu \mathrm{g}$. per ml. (standard deviation, \pm 7 per cent) ; mean, $22.5 \mu \mathrm{g}$. per ml. (standard deviation, \pm 8.5 per cent ) ; mean, $45 \mu \mathrm{g}$. per $\mathrm{ml}$. (standard deviation, \pm 11 per cent). These results were obtained by the same individual over a period of seven months.

\section{Serum streptomycin levels at six hours after a single intramuscular loading dose}

The distribution of values for antimicrobiallyactive levels of serum streptomycin at six hours after an intramuscular test dose of $20 \mathrm{mg}$. streptomycin sulfate per $\mathrm{Kg}$. of body weight in 166 hospitalized adult tuberculous patients are presented in Table IV.

\section{J. Reproducibility of serum streptomycin level studies on the same individuals}

Among the 157 patients who received loading dosage of $20 \mathrm{mg}$. streptomycin per $\mathrm{Kg}$. of body weight on two different occasions, the standard
TABLE IV

Serum streptomycin levels* at six hours after $20 \mathrm{mg}$. streptomycin per Kg. (166 patients)

\begin{tabular}{cccc}
\hline \hline $\begin{array}{c}\text { <10 } \mu \mathrm{g} . \\
\text { per ml. }\end{array}$ & $\begin{array}{c}10-19 \mu \mathrm{g} . \\
\text { per ml. }\end{array}$ & $\begin{array}{c}20-29 \mu \mathrm{g} . \\
\text { per ml. }\end{array}$ & $\begin{array}{c}30 \text { or }>\mu \mathrm{g} . \\
\text { per ml. }\end{array}$ \\
\hline 6 & 72 & 58 & 30 \\
$4 \%$ & $43 \%$ & $35 \%$ & $18 \%$
\end{tabular}

* Filter-paper disc-agar diffusion method using B. subtilis.

deviation from the mean of the results of the two studies was \pm 12 per cent. All patients had levels between 5 and $48 \mu \mathrm{g}$. streptomycin per $\mathrm{ml}$. of serum at six hours after the $20 \mathrm{mg}$. per $\mathrm{Kg}$. of body weight dosage.

$K$. Correlation of in vitro drug resistance with serum streptomycin levels achieved by patients excreting resistant organisms

The results of this study are presented in Table V. Statistical analysis of the difference between the two groups shows that it is highly significant $(\mathrm{p}<0.01)$.

TABLE V

Correlation of streptomycin serum levels and levels of streptomycin resistance of tubercle bacilli recovered from 33 tuberculosis patients previously treated with streptomycin

\begin{tabular}{|c|c|c|c|}
\hline \multicolumn{2}{|c|}{ Group 1* } & \multicolumn{2}{|c|}{ Group $2 \dagger$} \\
\hline Patient & $\begin{array}{l}\text { Streptomycin } \\
\text { serum levelf }\end{array}$ & Patient & $\begin{array}{l}\text { Streptomycin } \\
\text { serum levelf }\end{array}$ \\
\hline \multicolumn{2}{|c|}{$\mu g . / \mathrm{ml}$. } & \multicolumn{2}{|c|}{$\mu g . / m l}$. \\
\hline L.A. & 5 & B.S. & 15 \\
\hline R.W. & 5 & F.B. & 20 \\
\hline L.W. & 9 & R.E. & 20 \\
\hline M.B. & 10 & D.G. & 20 \\
\hline K. C. & 10 & E.M & 20 \\
\hline I.G. & 10 & F.N. & 20 \\
\hline B.L. & 10 & O.R. & 20 \\
\hline L.S. & 10 & G.S. & 20 \\
\hline W.A. & 15 & G.B. & 30 \\
\hline R.N.B. & 15 & G.O. & 30 \\
\hline M.M. & 15 & G.S. & 30 \\
\hline H.S. & 15 & H. W. & 30 \\
\hline R.B. & 20 & M.S. & 35 \\
\hline W.R. & 20 & G.C. & 40 \\
\hline G.W. & 20 & I.H. & 40 \\
\hline C.B. & 30 & G.M. & 40 \\
\hline & & P.H. & 50 \\
\hline
\end{tabular}

* Excreting populations resistant to $2 \mu \mathrm{g}$. streptomycin per $\mathrm{ml}$. and less than 50 per cent resistant to $10 \mu \mathrm{g}$. streptomycin per $\mathrm{ml}$.

† Excreting populations resistant to $2 \mu \mathrm{g}$. streptomycin per $\mathrm{ml}$. and more than 50 per cent resistant to $10 \mu \mathrm{g}$. streptomycin per $\mathrm{ml}$.

$\ddagger$ At six hours after a loading does of $20 \mathrm{mg}$. streptomycin sulfate per $\mathrm{Kg}$. of body weight. 


\section{DISCUSSION}

A wide variety of factors determine the effectiveness of chemotherapy of any infectious process. The situation is particularly complex when problems such as diffusion through host tissues and into phagocytes, antagonism, and metabolic alteration of the agent to inactive derivatives by chemical components of the inflammatory or necrotic lesion are involved. Delivery of antimicrobially-effective concentrations of the various agents to the multiplying parasites is of prime importance. Drug serum levels may serve as a reliable means of estimating such delivery.

In the absence of a satisfactory method for the chemical determination of free, antimicrobially-active isoniazid, the microbiologic assay method employed here is shown by these studies to be sufficiently accurate, simple and reproducible for clinical purposes. The wide variations in the rate and degree of biochemical alteration of the isoniazid molecule in different subjects, and the relative constancy for a given individual, as previously reported $(3,9,22)$, have been confirmed. Also, there is no doubt that higher dosages of isoniazid lead to higher serum levels of antimicrobially-active drug.

Certain clinical observations (24) suggested that daily dosages of isoniazid higher than 3 to $5 \mathrm{mg}$. per $\mathrm{Kg}$. of body weight should result in better chemotherapeutic response. However, there was no experimental evidence of a relationship between serum levels of this drug and response of human beings to treatment until our demonstration (9) of a highly significant relationship between serum isoniazid levels and the catalase activities of drug-resistant tubercle bacilli from isoniazid-treated patients. Then, it became evident that the serum level of antimicrobially-active isoniazid achieved in an individual depends on whether the subject is a "slow" or "rapid" inactivator as well as on the dosage of drug that he receives.

Approximately 45 per cent of the 254 subjects tested failed to achieve a level of at least $0.8 \mu \mathrm{g}$. per $\mathrm{ml}$. at six hours after a $4 \mathrm{mg}$. per $\mathrm{Kg}$. dose. Inasmuch as a high proportion of the patients studied were known drug treatment failures on admission to National Jewish Hospital, and failure can be a consequence of inadequate delivery of at least one of the drugs to the multiplying tubercle bacilli in vivo, this percentage may be higher than might be found in an unselected population of tuberculous patients.

The studies described here comparing the antimicrobially-active isoniazid level of serum with that of cavity content provide evidence that the serum level can be used fairly as a basis for estimating the concentration of isoniazid delivered to the multiplying bacilli in cavities. They also show that there is no important physicochemical barrier which interferes with the movement of antimicrobially-active isoniazid through cavity walls.

The results of previous studies have shown (9, 25) that the dosage of isoniazid which avoids the emergence of catalase-positive, weakly isoniazidresistant mutants is one which provides an antimicrobially-active isoniazid serum level of at least $0.4 \mu \mathrm{g}$. per ml. at six hours following one-half of the total daily dose. As previously indicated (1), this dosage yields drug levels in vivo which are much higher than necessary to avoid the emergence of any drug-resistant mutants when a second drug is employed, such as streptomycin, also in adequate dosage on combined drug treatment. Therefore, an optimal chemotherapeutic response may be anticipated (and with a wide margin of safety) in original treatment patients excreting drug-susceptible populations of tubercle bacilli if one-half of the total daily dose of isoniazid gives a serum level of at least $0.4 \mu \mathrm{g}$. per $\mathrm{ml}$.

An increase in the level of antimicrobially-active drug to insure that all patients will maintain adequate serum levels of isoniazid may be accomplished either by increasing the dosage of isoniazid or by employing drugs which apparently prevent rapid inactivation of the drug. An increase in dosage of isoniazid to 16 to $24 \mathrm{mg}$. per $\mathrm{Kg}$. daily without pyridoxine has led to a prohibitive increase in isoniazid neuropathy (24). The simultaneous administration of pyridoxine with isoniazid has reduced but not completely prevented toxicity due to isoniazid $(24,26)$. Some few subjects inactivate isoniazid so rapidly that dosages of 16 to $20 \mathrm{mg}$. per $\mathrm{Kg}$. per day are insufficient to maintain adequate, antimicrobially-active, serum isoniazid levels. It is in these patients that high dosage plus the concomitant administration of drugs such as paraaminosalicylic acid or para-aminobenzoic acid may be employed. A decrease in the rate of metabolic alteration of isoniazid by these drugs has been attributed to competition for the biochemical proc- 
ess of acetylation $(27,28)$. The action of paraaminosalicylic acid on the antimicrobially-active serum isoniazid level suggests that the effectiveness of combined therapy employing isoniazid and para-aminosalicylic acid (29) is due not only to the antimicrobial activity of each drug, but also to the resulting elevation of the antimicrobially-active serum isoniazid level.

It seems fair to conclude that to achieve optimal therapeutic results and to reduce the incidence and severity of the toxic effects of the drug, serum levels of antimicrobially-active isoniazid should be known. The dosage of isoniazid which should be employed is clearly related to the rate at which the patient inactivates the drug; and it would seem that this can be measured satisfactorily by the microbiologic assay method.

While streptomycin does not appear to be subject to metabolic alteration in man (15), the problem of adequate delivery of the drug to multiplying tubercle bacilli is very complicated (30). Not all intramuscular injections (as routinely administered) are actually into muscle tissue. Absorption from such an "intramuscular" depot is influenced by factors such as inflammatory response and blood supply. Some subjects excrete streptomycin more rapidly than others. All other factors being equal (which they seldom are), heavy subjects should achieve relatively lower tissue concentrations than light subjects on a conventional $1.0 \mathrm{Gm}$. dosage schedule. There are also chemical components of inflammatory or necrotic tissue, such as nucleic acids, which antagonize the antimicrobial action of streptomycin (31-33). Finally, the activity of streptomycin is modified by the concentration of viable tubercle bacilli exposed to it. Such uncontrollable variables render hazardous any attempt to correlate the concentration of streptomycin achieved in the serum with the actual delivery of the drug in an active form to tubercle bacilli in patients.

In spite of the uncontrollable modifying factors, it was considered important to know that at least the first step in the delivery of sufficient concentrations of streptomycin had been achieved. Accordingly, serum levels of antimicrobially-active streptomycin sulfate were determined. These confirmed previous reports that variations do exist between subjects $(16,34)$.

The results of the studies which relate the levels of drug resistance of streptomycin-resistant mutants excreted by patients previously treated with streptomycin and the concentrations of streptomycin which are found in their sera after the standard test are significant. As in previous similar studies with isoniazid (9), these observations establish the six hour serum assay for streptomycin as a reliable basis for estimating the concentration of this drug delivered to multiplying tubercle bacilli in most patients. Thus, in spite of the indeterminable local factors which influence the antimicrobial activity of streptomycin, humoral levels of the drug play an important role.

\section{SUMMARY}

The results of microbiologic assays for antimicrobially-active isoniazid in serum and tuberculous cavity content are presented. Some effects of change in dosage of isoniazid and of concomitant administration of various other drugs on the antimicrobially-active serum isoniazid levels in patients are reported. Para-aminosalicylic acid and para-aminobenzoic acid were the only drugs studied that significantly increased this level.

The results of application of a microbiologic assay method for serum streptomycin are also presented, and, as previously shown for isoniazid, a significant relationship is demonstrated between serum levels of streptomycin and certain aspects of the microbiologic response in patients to streptomycin treatment.

The clinical implications of the variations in antimicrobially-active serum levels of both isoniazid and streptomycin achieved by different patients are discussed.

\section{REFERENCES}

1. Cohn, M. L., Middlebrook, G., and Russell, W. F., Jr. Combined drug treatment of tuberculosis. I. Prevention of emergence of mutant populations of tubercle bacilli resistant to both streptomycin and isoniazid in vitro. J. clin. Invest. 1959, 38, 1349.

2. Mandel, W., Cohn, M. L., Russell, W. F., Jr., and Middlebrook, G. Effect of para-aminosalicylic acid on serum isoniazid levels in man. Proc. Soc. exp. Biol. (N. Y.) 1956, 91, 409.

3. Morse, W. C., Curry, F. J., Morse, P. Z., Chambers, J. S., and Lincoln, A. F. Effect of oral PAS on biologically active isoniazid serum levels in Transactions of the 15th Conference on the Chemotherapy of Tuberculosis. St. Louis, Mo., 1956, vol. 15 , p. 283. 
4. Bernstein, J., Lott, W. A., Steinberg, B. A., and Yale, H. L. Chemotherapy of experimental tuberculosis. V. Isonicotonic acid hydrazide (Nydrazid) and related compounds. Amer. Rev. Tuberc. 1952, 65, 357.

5. Hughes, H. B. On the metabolic fate of isoniazid. J. Pharmacol. exp. Ther. 1953, 109, 444.

6. Bönicke, R., and Reif, W. Ensymatische Inaktivierung von Isonicotinsäure-hydrazid im menschlichen und tierischen Organismus. Naunyn-Schmiedeberg's Arch. exp. Path. Pharmak. 1953, 220, 321.

7. Cuthbertson, W. F. J., Ireland, D. M., Wolff, W., and Kuper, S. W. A. Method of estimating isoniazid in biological fluids. Brit. med. J. 1954, 1, 609.

8. Hughes, H. B., Schmidt, C. H., and Biehl, J. P. The metabolism of isoniazid: Its implications in therapeutic use in Transactions of the 14th Conference on Chemotherapy of Tuberculosis. Atlanta, Ga., 1955 , vol. 14, p. 217.

9. Mandel, W., Cohn, M. L., Russell, W. F., Jr., and Middlebrook, G. Serum isoniazid levels and catalase activities of tubercle bacilli from isoniazidtreated patients. Amer. J. med. Sci. 1957, 233, 66.

10. Rubin, S. H., Drekter, L., Scheiner, J., and De Ritter, E. Determination of blood plasma levels of hydrazine derivatives of isonicotinic acid. Dis. Chest 1952, 21, 439.

11. Kelly, J. M., and Poet, R. B. The estimation of isonicotinic acid hydrazide (Nydrazid) in biologic fluids. Amer. Rev. Tuberc. 1952, 65, 484.

12. Short, E. I. Estimation of isoniazid. Lancet 1954, 1, 656.

13. Prescott, B., Katz, S., and Kauffmann, G. A rapid colorimetric method for the determination of isonicotinic acid hydrazide in blood plasma. II. Application to blood plasma from human tuberculosis patients. J. Lab. clin. Med. 1954, 44, 600.

14. Maher, J. R., Whitney, J. M., Chambers, J. S., and Stanonis, D. J. The quantitative determination of isoniazid and para-aminosalicylic acid in body fluids. Amer. Rev. Tuberc. 1957, 76, 852.

15. Rake, G., and Donovick, R. Absorption, distribution, and excretion of streptomycin in Streptomycin, $\mathrm{Na}$ ture and Practical Applications, S. A. Waksman, Ed. Baltimore, Williams \& Wilkins Co., 1949, p. 236.

16. Kornegay, G. B., Forgacs, J., and Henley, T. F. Studies on streptomycin. II. Blood levels and urinary excretion in man and animals. J. Lab. clin. Med. 1946, 31, 523.

17. Boxer, G. E., Jelinek, V. C., Tompsett, R., DuBois, R., and Edison, A. O. Streptomycin in the blood: Chemical determinations after single and repeated intramuscular injections. J. Pharm. exp. Ther. 1948, 92, 226.

18. Molitor, H. Pharmacology of streptomycin. Bull. N. Y. Acad. Med. 1947, 23, 196.

19. Rake, G., Pansy, F. E., Jambor, W. P., and Donovick, R. Further studies on the dihydrostreptomycins. Amer. Rev. Tuberc. 1948, 58, 479.
20. Weiser, O. L., Howard, O. P., and Dye, W. E. Assay of streptomycin in resected lung tissue: A preliminary report in Transactions of the 12th Conference on the Chemotherapy of Tuberculosis. Atlanta, Ga., 1953, vol. 12, p. 198.

21. McCune, R., Deuschle, K., and McDermott, W. The delayed appearance of isoniazid antagonism by pyridoxine in vivo. Amer. Rev. Tuberc. 1957, 76, 1100.

22. Bell, J. C., and Mitchell, R. S. The effect of some aromatic amines on serum isoniazid levels in Transactions of the 16th Conference on the Chemotherapy of Tuberculosis. St. Louis, Mo., 1957, vol. 16, p. 105.

23. Forgacs, J., Kornegay, G. B., and Henley, T. F. Studies on streptomycin. I. Assay in body fluids. J. Lab. clin. Med. 1946, 31, 514.

24. Middlebrook, G., and Dressler, S. H. Clinical evaluation of isoniazid. Amer. Rev. Tuberc. 1954, 70, 1102.

25. Bell, J. C., and Riemensnider, D. K. Use of a serum microbiologic assay technique for estimating patterns of isoniazid metabolism. Amer. Rev. Tuberc. 1957, 75, 995.

26. Biehl, J. P., and Vilter, R. W. Effect of isoniazid on vitamin $B_{6}$ metabolism: Its possible significance in producing isoniazid neuritis. Proc. Soc. exp. Biol. (N. Y.) 1954, 85, 389.

27. Carlson, H. B., Anthony, E. M., Russell, W. F., Jr., and Middlebrook, G. Prophylaxis of isoniazid neuropathy with pyridoxine. New Engl. J. Med. 1956, 255, 119.

28. Johnson, W. J. Biological acetylation of isoniazid. Nature (Lond.) 1954, 174, 744.

29. Johnson, W. J., and Corte, G. Inhibition of isoniazid acetylation in vitro and in vivo. Proc. Soc. exp. Biol. (N. Y.) 1956, 92, 446.

30. Tucker, W. B. Intepretation of data from the cooperative study of the chemotherapy of pulmonary tuberculosis: General regimens in Transactions of the 15th Conference on the Chemotherapy of $\mathrm{Tu}$ berculosis. St. Louis, Mo., 1956, vol. 15, p. 39.

31. Davis, B. D. The binding of chemotherapeutic agents to proteins and its effect on their distribution and activity in Evaluation of Chemotherapeutic Agents, C. M. MacLeod, Ed. New York, Columbia University Press, 1949, p. 44.

32. Geiger, W. B., Green, S. R., and Waksman, S. A. The inactivation of streptomycin and its practical applications. Proc. Soc. exp. Biol (N. Y.) 1946, $61,187$.

33. Davis, B. D., and McDermott, W. Principles of chemotherapy in Bacterial and Mycotic Infections of Man, R. J. Dubos, Ed. Philadelphia, J. B. Lippincott, 1952, p. 726.

34. Mitchison, D. A., and Spicer, C. C. A method of estimating streptomycin in serum and other body fluids by diffusion through agar enclosed in glass tubes. J. gen. Microbiol. 1949, 3, 184. 